\title{
New ways of teaching geomatics courses in forestry: Online delivery
}

\author{
by Brigitte Leblon ${ }^{1,2}$, Armand LaRocque ${ }^{1}$, Glen A. Jordan ${ }^{1}$ and María Luz Gil ${ }^{3}$
}

\begin{abstract}
Lectures and supervised laboratory sessions are the classical methods of teaching geomatics (GISscience, photo-interpretation and remote sensing) courses. This paper describes a new teaching method that uses multimedia and Internet technology in offering self-paced, web-based courses. Advantages and disadvantages of each method are presented.
\end{abstract}

Key words: teaching, remote sensing, GISscience, photo-interpretation Internet, multimedia.

\section{RÉSUMÉ}

La méthode classique pour enseigner la géomatique (SIG, photo-interprétation, télédétection) se fait via des cours magistraux et des sessions de laboratoire supervisées. L'article présente une nouvelle méthode d’enseignement qui utilise la technologie multimédia et Internet via des cours en ligne sur Internet. Les avantages et inconvénients de chaque méthode sont présentés.

Mots-clés : enseignement, télédétection, SIGs, photo-interprétation, Internet, multimédia.

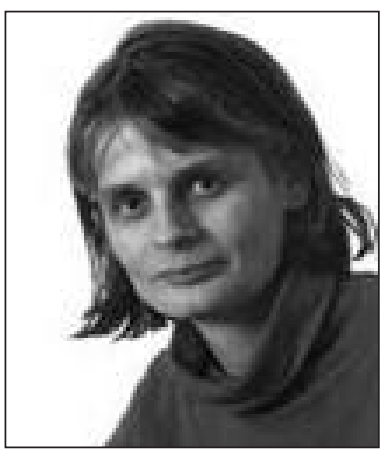

Brigitte Leblon

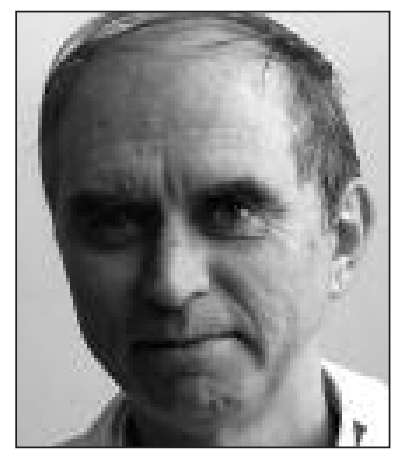

Armand LaRocque

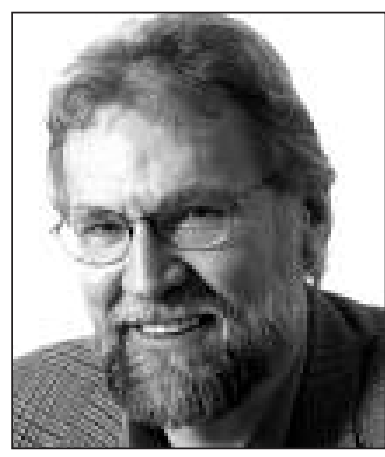

Glen A. Jordan

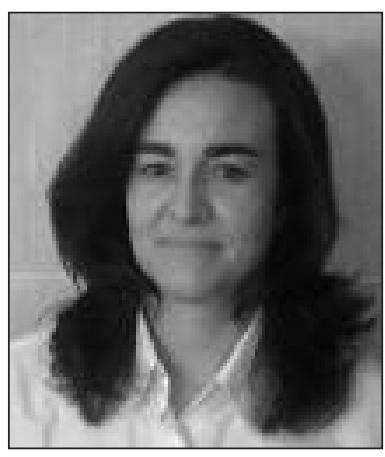

María Luz Gil

\section{Introduction}

With development of the digital world and of new satellite sensors, there is currently an increasing demand for geomatics training, namely in remote sensing, GISscience and photointerpretation. Traditionally, courses in these areas have been taught at the university level, mainly in geography and forestry departments, with theoretical material presented in the classroom, and practical applications delivered through supervised laboratory exercises. With development of Internet, multimedia and teaching software technology, it is now possible to teach remote sensing, GIS and photo-interpretation over the Internet through self-paced and web-based online courses. Since 1996, several online geomatics courses have been developed at the Faculty of Forestry and Environmental Management, University of New Brunswick (UNB), Fredericton (Canada) (Table 1). Each course is different from free online tutorials because it has theoretical quizzes, practi-

cal exercises and an exam. It also differs from software on-line helps and tutorials because it has a full explanation of theoretical concepts used in the software.

In this paper the new teaching method is described and assessed using examples taken from an online course in digital image processing, developed by the corresponding author. The course, FOR 4313 Digital Image Processing in Remote Sensing, has been offered since 1997 in both French and English, and is now also offered in Spanish. It is currently part of two academic programs at UNB: the Bachelor of Science in Forestry program offered at the Faculty of Forestry and Environmental Management, and the continuing education Open Access Learning Program (OALP) offered through the UNB College of Extended Learning. The latter is a self-paced, guided, independent study program, designed to offer UNB courses and services to individuals wishing to continue their formal education, but who currently are not served by

\footnotetext{
${ }^{1}$ Faculty of Forestry and Environmental Management, University of New Brunswick, P.O. Box 44555, Fredericton, New Brunswick E3B 6C2. ${ }^{2}$ Corresponding author. E-mail: bleblon@unb.ca

${ }^{3}$ Universidad Santiago de Compostela, Departmento de Ingeniería Agroforestal, Spain
} 
Table 1. List of geomatics courses offered as online courses at the Faculty of Forestry and Environmental Management, University of New Brunswick, Fredericton ${ }^{\mathrm{a}}$

\begin{tabular}{|c|c|c|c|c|c|}
\hline Level & Number & Title & Area & Language & $\begin{array}{l}\text { Course } \\
\text { developers }\end{array}$ \\
\hline High School & FOR 1285 & Introduction to GIS in forestry (ArcView 3) & GIS & English & Jordan 1998 \\
\hline \multirow[t]{8}{*}{ Undergraduate } & FOR 2285 & GIS in forestry I (ArcGIS) & GIS & English & Jordan 2005 \\
\hline & FOR 2286 & $\begin{array}{l}\text { GIS in Forestry II (spatial analysis } \\
\text { and modelling) }\end{array}$ & GIS & English & Jordan 2007 \\
\hline & FOR 3303 & $\begin{array}{l}\text { Photogrammetry, photo-interpretation } \\
\text { and remote sensing in forestry }\end{array}$ & $\begin{array}{l}\text { Photo-Interpretation/ } \\
\text { Remote Sensing }\end{array}$ & English & $\begin{array}{l}\text { Leblon and } \\
\text { LaRocque } 1999\end{array}$ \\
\hline & FE 3306 & Photo-interpretation for engineers & Photo-Interpretation & English/French & $\begin{array}{l}\text { Leblon and } \\
\text { LaRocque } 2003\end{array}$ \\
\hline & FOR 4286 & Géomatique avec ArcGIS & GIS & French & $\begin{array}{l}\text { LaRocque and } \\
\text { Leblon } 2004\end{array}$ \\
\hline & FOR 4303 & $\begin{array}{l}\text { Optical, thermal infrared and radar } \\
\text { remote sensing }\end{array}$ & Remote Sensing & English/French & Leblon 2000 \\
\hline & FOR 4304 & RADARSAT-2 and polarimetric SAR images & Remote Sensing & $\begin{array}{l}\text { English/French/ } \\
\text { Spanish }\end{array}$ & $\begin{array}{l}\text { Leblon } 2008 \\
\text { Gil } 2008\end{array}$ \\
\hline & FOR 4313 & Digital image processing in remote sensing & Remote Sensing & $\begin{array}{l}\text { English/French/ } \\
\text { Spanish }\end{array}$ & $\begin{array}{l}\text { Leblon } 1999 \\
\text { Gil } 2005\end{array}$ \\
\hline \multirow[t]{6}{*}{ Graduate } & FOR 6283 & Spatial analysis and modelling & GIS & English & Jordan 2005 \\
\hline & FOR 6284 & Advanced ArcGIS in forestry & GIS & English & Jordan 2007 \\
\hline & FOR 6286 & Géomatique avec ArcGIS & GIS & French & $\begin{array}{l}\text { LaRocque and } \\
\text { Leblon } 2004\end{array}$ \\
\hline & FOR 6302 & $\begin{array}{l}\text { Advanced studies in optical, thermal } \\
\text { infrared and radar remote sensing }\end{array}$ & Remote Sensing & English/French & Leblon 2000 \\
\hline & FOR 6304 & $\begin{array}{l}\text { Advanced studies in RADARSAT-2 } \\
\text { and polarimetric SAR images }\end{array}$ & Remote Sensing & $\begin{array}{l}\text { English/French/ } \\
\text { Spanish }\end{array}$ & $\begin{array}{l}\text { Leblon } 2008 \\
\text { Gil } 2008\end{array}$ \\
\hline & FOR 6313 & $\begin{array}{l}\text { Advanced studies in digital image } \\
\text { processing in remote sensing }\end{array}$ & Remote Sensing & $\begin{array}{l}\text { English/French/ } \\
\text { Spanish }\end{array}$ & $\begin{array}{l}\text { Leblon } 1999 \\
\text { Gil } 2005\end{array}$ \\
\hline
\end{tabular}

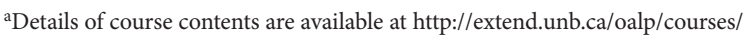

conventional classroom-based courses. It is delivered through the Blackboard teaching platform. The image processing software taught through the practical course exercises is a professional one made by a Canadian company, PCI Geomatics.

\section{Online Method}

Online course material is the only source of course information for students taking FOR 4313. The course is not delivered through scheduled lectures and laboratory sessions. It comprises 11 chapters. While it is recommended that students complete one online chapter a week, i.e., theoretical quiz and practical laboratory exercise, some students can finish the course in one month, completing two or three chapters per week.
When entering into the course via Blackboard, the course home page is displayed. It has the following icons:

1. The "Syllabus" icon links to the course syllabus that describes course objectives, outline, modus operandi, and grading scheme.

2. Chapter and laboratory course material is accessible through the "All the Chapters" and "All the Labs" icons, respectively.

3. If students have questions or comments about the course, they may use the "Questions?Comments?" icon, where emails may be sent to the entire virtual class (including the instructor). Peer-teaching can then occur as in classrooms.

4. The "Glossary" icon gives access to the "Glossary of remote sensing terms" from the Canadian Centre of Remote Sens- 
ing, which is available in both French (http://ccrs.nrcan. gc.ca/glossary/index_f.php) and English (http://ccrs. nrcan.gc.ca/glossary/index_e.php).

Practical laboratories make use of professional image processing software, GEOMATICA, developed by PCI Geomatics. Students are supposed to know usage of ArcGIS 9 as GIS software, hence FOR 2285 is a prerequisite for FOR 4313. Images and GIS layers used in the practical exercises can be downloaded from an online accessible database (http:// www.unbf.ca/forestry/woodlot/Inventory91.html) through the UNB Woodlot icon. Additional data can be downloaded directly from the course home page. For example, the image used in the course is the full LANDSAT-TM image over Fredericton in GEOMATICA format, which is downloadable through the "fred.pix" icon, while the UNB Woodlot portion of this image is downloadable through the UNB Woodlot icon. Laboratory reports have to be handled through e-mail to the instructor or through the course page assignment tool of Blackboard.

Each of the theoretical and practical parts has specific learning objectives that allow its positioning in the whole course outline. While laboratory reports require manual marking, theoretical quizzes are automatically graded. Indeed, theoretical quizzes consist of multiple choice or matching-type questions that include feedback for incorrect responses. However, answering questions is not straightforward, as they usually require students to perform some computations or some procedures using course data and software. Quizzes can be reached using the "Assessment" tool of the Blackboard system. The exam is designed as a theoretical quiz. Finally, besides ongoing e-mail contact with students, student progress can be tracked using the Blackboard system.

\section{Comparison of Classical and Online Methods}

Online teaching offers advantages over the classical method (Table 2). Major advantages are related to course preparedness and flexibility in terms of timing, language and audience. For example, half the current FOR4313 class are undergraduate students located in New Brunswick, but the other half are graduate students and continuing education students located in Ontario, Québec, Newfoundland, Alberta, Yukon, Belgium, France, Japan, Taiwan, USA and Australia. Also, with the online approach and its less time-consuming marking procedure, the instructor can more easily detect weak students and dedicate more time to them. This allows strong students to proceed on their own. Further, illustrations presented

Table 2. Comparison of classical and online teaching methods ${ }^{a}$

\begin{tabular}{|c|c|c|}
\hline Criterion & Classical method & Online method \\
\hline Interactions & Face-to-face & E-mail and tracking system \\
\hline Learning schedule & Time tabled & According to student's own schedule \\
\hline Student progression & Depends on the classmates & At their own speed \\
\hline Teaching language & Single & Multiple \\
\hline Audience & Classroom & Worldwide \\
\hline Student groups & Single & Multiple \\
\hline Course preparedness & Can be poor & Well prepared, structured, organized \\
\hline Course preparation time & Less time-consuming & Time-consuming \\
\hline $\begin{array}{l}\text { Instructor time dedicated } \\
\text { to weak students }\end{array}$ & $\begin{array}{l}\text { Low, because time is shared with strong students, } \\
\text { and more time is needed for marking }\end{array}$ & $\begin{array}{l}\text { High, because strong students can go on their own, } \\
\text { and less time is needed for marking }\end{array}$ \\
\hline Student attitude & Tendency to be passive & $\begin{array}{l}\text { Active learning experience, development of } \\
\text { autonomic skills }\end{array}$ \\
\hline Course content & Limited & $\begin{array}{l}\text { Unlimited, because of possible linkages to other } \\
\text { web-based contents }\end{array}$ \\
\hline Illustrations & Static & Animated \\
\hline Field laboratory & Possible & Not possible \\
\hline Quiz questions & All types possible & $\begin{array}{l}\text { Only some types possible (short answer, matching, } \\
\text { calculation, multiple, choice) }\end{array}$ \\
\hline Class material & Chalk, blackboard, room & Teaching platform (BlackBoard), web browser \\
\hline
\end{tabular}

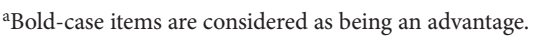


throughout an online course can be easily animated, which can make their messages more understandable. Online courses can also readily provide background information to the learners through linkages to relevant web-based pages. Such advantages do not exist with classroom teaching. Main disadvantages relate to preparation time, impossibility of field teaching, lack of face-to-face interactions, limited types of quiz questions, and costs associated with online technology (teaching platform, web browser). Discussions are now underway in an effort to combine all these courses into an online certificate.

\section{Acknowledgments}

The authors thank the numerous students who have taken online geomatics courses and given useful feedback on course content and modus operandi. Development of these courses was funded by UNB through the OALP program. A threeyear Canadian Space Agency grant awarded to B. Leblon partially funded development of FOR 4304 and FOR 6304. Development of FOR 4304 and FOR 6304 was possible thanks to assistance of CCRS (F. Charbonneau, J. Van Der Sanden, R. Touzi) and of MDA (G. Staples). The authors thank Dr. G.R. Powell for careful review of the paper. 